\title{
Evlenmeden doğan kanun ihtilâfları
}

\author{
Asistan Jale Güral
}

\section{G I R I S}

Kadın ile erkeğin, yeni bir aile kurmak ve biribirlerine karşı sadakat ve muavenette bulunmak üzere meşru bir surette birleşmeleri, demek olan evlenme; (1) Devletler hususî hukuk alanında en çok kanun ihtilâflarına meydan veren akitlerden biridir. Bu gün artık, jus connubium yerli ve yabancı farkı gözetilmeden herkese tanınan bir hak mahiyetini almıștır. Fakat evlenme akti hakkında, muhtelif Devlet kanunları arasinda bir birlik mevcut olmaması, her devletin evlenmenin shhhatı, evlenme aktinin inikadı için gerek esas ve gerekse șekil bakımından türlü türlü hükümler koymus olmaları; kanun ihtilâflarının doğumuna sebebiyet vermektedir. Modern hayatın icapları dolayısiyle devletler arasında gittikçe artan sıkı münasebetler ve temaslar, muhtelif devlet vatandaşları arasmdaki evlenmelerin çoğalmasın mucip olarak bu ihtilâfları daha da girift bir hale sokmaktadır.

Evlenmeden doğan kanun ihtilâflarının hallinde birçok müş̧üller kendini gösterir. Evlenme ile meydana gelen aile; devletin temelini teşkil ettiğinden onun sağlam bir surette kurulmasınt ve teşkilâtlanmasin her devlet kendi güvenliğinin başinda görür; bunun için de kendi vatandaşlarmm hariçte bile aktedecekleri evlenmelerin, sadece kendi kanununa tâbi olmasını ister. Bundan başka prensip olarak kabul edilen aslî şartlara Millî kanunun, surî, şartlara mahalli kanunun uygulanmasına da ayni görüss ve âmme intizamı gaygusiyle bir çok tahditler kor. İşte bütün bunlar itilâfların çoğalmasina ve yeknesak bir şekilde halledilmesine mâni teşkil eder.

Evlenmenin aslî şartları:

Prensip: Millî̀ kanunun tatbikidir:

Evlenmenin aslî şartları, evlenme aktinin kurulabilmesi ve sıh-

(1) E. Arsebük: Sa: 546. 
hati için lüzumlu olan şartlardır. Bu şartlar denlebilir ki bir taraf$\tan$ müstakbel evlileri göz önünde tutarak onları hattâ kendi kenkendilerine karşı himaye ve kurulacak evlilik birliğini sıyanet, diğer taraftan da cemiyetin içtimaî, ahlâkî ve bazen dinî telâkkileri başka bir deyimle intizamı âmmesi nazara alınarak konmuş olan hükümlerdir. Bunun içindir ki muhtelif Devletler arasinda önemli farklar gösterir.

Evlenmenin aslî şartları prensip olarak, evleneceklerin Millî kanununa tâbidir. Bu prensip Lâhey anlaşmasının birinci maddesiyle teyit edilmiş ve bazı istisnalar hariç bütün kara Avrupa devletleri kanunlariyle, Çin ye Japon kanunu tarafından kabıl olunmuştur (2).

Türk kanun vazı tarafından kabul edilmis olan sistem de budur. Bu, sarih olarak kapitülâsyonlarm lâğvı üzerine 1915 (1330) da neşredilen "Memaliki osmaniyede bulunan ecnebilerin hukuk ve vezaifi hakkındaki kanunu muvakkatin» 4 üncü maddesinde tasrih edilmiştir. Madde şöyle der: «...... Şu kadar ki gayri müslim teb'ayı ecnebiyeye müteallik olup ta akit ve feshi nikâh ve tefriki ebden ve übüvvet ve nesep ve tebenni gibi hukuku aileye ve rüşt ve mezuniyet ve hacir ve vesayet gibi ehliyete müteallik bulunan dâvaların mehakimi osmaniyede rüyet edilebilmesi... şartlara mütevakkuftır, ve bu suretle intizamı âmmei Devlete nugayir olmamak şartiyle alâkadarların hükûmeti metbuaları kavarinine ve intilâfı kavanin halinde hukuku hususiyei düvel kavaidine tevfikan muamele olunur». (3). Bu madde yabanclların, şahsî halleri hakkmda kendi Millî kanunlarının tatbiki lüzumunu beyan ettikten sonra alâkadarların muhtelif tabiiyette bulunması halinde de çıkacak ihtilâfın hallini D. H. H. havale eder (4).

Bundan anlaşliyor $\mathrm{ki}$ bu vaziyette de yine alâkadarların kendi Millŝ kanunları uygulanacaktır. Çünkü D. H. H. ca kabul edilmiş prensip budur.

Muvakkat kanunda Türklerin ecnebi memleketlerde şahsî halleri ve dolayısiyle evlenme ehliyetleri bakımından hangi kanunlara tâbi olacakları hakkında bir hüküm yoktur. Diğer kanunlarımızda da böyle bir hükme tesadüf edemedik. Fakat hem D. H. H. prensipleri ve hem de Türkiyenin D. H. H. sistemi bakimndan yabancı

(2) Fransız medenî K. M: 170, 171; Alman meriyet kanunu M: 1314, Isviçre meriyet $\mathrm{K} . \mathrm{M}: 59 / 7 \mathrm{C}:$ Audinet: Sa. 177 .

(3) Sevig: Türk kanunlar ihtilâfı sentezi: Sa. 36 vđ; Droit International privé Turc, Repertoire cilt 7. Sa. 264; Sicilli Kavanin, cilt 36: Sa: 658.

(4) Sevig: Türk kanunlar ihtilâfr sentezi. Sa. 11. 
memleketteki Türklerin, kendi Millî kanunlarına tâbi olmaları icap eder (5), (6).

Fransadaki vaziyet bizdekinin aksidir. Fransız Medenî kanunu M. 171/1 Fransizların evlenme ehliyetlerinin kendi millî kanuniarına tâbi olacağını tasrih eder; fakat ecnebilerin bu hususta tâbi olacakları kanunu göstermez. İsviçre kanun koyucusu ikili bir yol t2kip eder. Meriyet kanunu M. 59/7 c ile Isviçrede evlenecek yabanclların, aslî şartlar bakımından kendi Millî kanunlarına tâbi olduklarmı kabul etmekle beraber ayni, maddenin 7 f fikrasında İsviçrelilerin, yabancı memleketlerde mahallî kanuna uygun olarak aktettikleri evlenmelerin; kanuna karşı hile yapılmış olmadıkça; Işviçrede muteber olacağını kabul eder. Demek oluyor ki İsviçre kanunu bazı hallerde aslî şartları akit mahallî kanununa "Lex loci'ye" tâbi kilarr.

1889 tarihli Cenubî Amerika Devletleri arasında aktedilmiș olan Monteviyedo mukavelesiyle aslî şartlara "Lex Locin nm tatbiki kararlaştırılmı ve bu husus bazı Cenubî Amerika Devletleri kanunlarına girmistir (7).

Şimalî Amerikada evlenmenin aslî şartları umumiyetle "Lex loc) ye tâbidir (8).

Aşağı yukarı bütün Anglo. Sakson memleketleriyle, Norveç ve Denimarkada aslî şartların ikametgâh kanununa (Lex Domicillì) ye tâbi oldukları kabul olunur. Fakat evlenmenin așî̀ ve surî şartları arasındaki farklar Ingiliz Jurisprudansı tarafindan kesin olarak tesbit edilmiş değildir (9):

Muhtelif kanun sistemleri arasındaki bu farklardan dolayıdır ki çok vakit bir meleket kanununa göre evli telâkki eđilen iki kimse; diğer bir memleket kanununa göre böyle telâkki olunmiyabilirler; veya bir memleket kanununca muteber addedilen bir evlenme diğer bir yerde batil olabilir.

(5) Metr Salem de ayni fikirdectir: Répertoire: cilt 7 Sa. 262 de der ki: Türk kanununun; ̧̧ahsî hạ bakımụdan yabanci mahkemelerin kazaî salahiyetini tanmaması ve ecnebi mahkemelerden verilen ahvali sahsiyeye dair jlâmlrın Türkiyede hị̣ bir suretle infaz kabiliyeti olmaması bakimindan da; yabancı memleketteki Türklerin șạsî hallerinin kendi kanunlarına tâbi olmasi lâzinđđir.

(6) Bc hususta bak Sevig ayni eser. Sa. $37 \mathrm{vd;}$ Usul kanunu M. 540/nu 4.

(7) Répertoire: cilt: 9 Sa: 28; Audinet: Sa; 178.

(8) T: Healy: Sa: 480 .

(9) Répettoire: citl: 6 Sa: 38. 


\section{ASLI ŞARTLARA TATBIK EDILECEK MILLî KANUNUN ŞÜMULÜ:}

Evlenmenin aslî şartlarm; evlenme ehliyeti (evlenmenin müsbet şartları) ve evlenmeye mâni sebepler (evlenmenin menfî şartları) diye iki kısma ayırmak icabeder.

Evlenme ehliyeti; evlenmenin teşekkülü için mevcut olması gerekli şartlardır.

Evlenmeye mâni sebepler ise sahi bir evlenmenin vücuduna mâni olan hallerdir.

a) Evlenmenin sıhhati için aranılan ehliyet: Prensip: Millî kanun.

İngilterede ikametgâh kanunu. Fakat İngilterede; bir İngiliz ile evlenecek yabancinın ikametgâh kanununa göre olan ehliyetsizliği; eğer kendisi İngiliz kanununun aradığı ehliyeti haiz ise nazara alınmaz (10).

Türk ve İsviçre kanun koyucusu evleneceklerde dört ehliyet şartı arar: yaş; temyiz kudreti; akıl sihhati; tarafların rızası.

1 -- Yaş: Mk. 88. Bir kimsenin hangi yaşta evleneceğini Millî kanunu tâyin eder. Çünkü vücudưn maddî olgunluğu ve fikrî inkişafı bakımından tesbit edilmiş bulunan evlenme yaşları; memleketten memlekete ve iklime göre değişir. Bunun içindir ki her memleketin hususî vaziyeti, iklimi, iktisadî ve manevî bünyesi göz önünde tutularak tâyin edilmiş olan bu yaşlar; yalnız o memleket ahalisine tatbik edilebilir.

Türkiyede yaş kaddi erkekler için on yedi, kadınlar için on beştir. Bazı fevkalâde hallerde bu yaş yargıcın hükmiyle kadın için on dört erkek için on beşe indirilebilir. Mk. 88/2. Fakat bu, Türkiyede evlenece kolan ve kendi millî kanununda böyle bir hüküm bulunmıyan yabancı devlet vatandaşlarina tatbik edilemez.

Belçika, Holanda, İtalya, Portekiz ve Fransada evlenme yaşı erkekler için on sekiz; kadm için Belçika, Fransa ve İtalyada on beş; Holanda ve Portekizde on altıdır. Fransız kanunu bu yaş hadlerinin bazı hallerde bir dispans ile daha aşağı inebileceğini kabul eder M. 144.

Bazı memleketlerde yaş haddi pek aşağı derecededir. Meselâ İspanya kanununa göre erkek on dört kız on iki yaşında evlenebilir (11).

(10) Pillet: Sa: 555.

(11) A. Kemal: Sa: 4521 . 
Ingilterede evlenme yaşı kadın ve erkek için yirmi bir yaş olarak tespit edilmiştir. Fakat erkekler on yedi ve kadmlar on beş yaşında kanuní mümessillerinin rızalariyle evlenebilirler (12). Kanunun aradı̆ ku batıl addeder (13).

Yaş meselesi hakkında yeni fakat makul olmıyan bir fikir ileri sürülmüştü. Bu fikre göre Millî kanunun evlenme yaşı olarak kabul eylediği yaş, mahallî kanunun kabul eylediğinden çok büyük olduğu hallerde mahallî kanun tatbik edilmelidir. Fakat bu görüş tarzı umumiyet üzere kabul edilmez (14).

Küçüklerin evlenebilmeleri için ana ve babalarının rızası şarttır Mk. 90, Fr. 148. Mk. Bizim kanunumuza göre aranllan rıza ana ve babanınkidir, bu hususta aralarında ihtilâf çıkarsa babanın reyi tercih edilmez. Halbuki Fransız kanunu böyle bir vaziyette babanın reyini kâfi görür.

Ingiliz hukukunda da aranllan muvafakat ana ve babanınkidir.

Ana ve babanın muvafakat etmemesine karşı bizde müracaat edilecek hiç bir makam yoktur. Kanunî mümessillerin rızası alınmadan yaplan bir evlenme ancak nisbî butlan ile batıldur. Fakat böyle bir butlan $\mathrm{Mk}$. 120 de gösterilen hallerin tahakkuku ile ortadan kalkar.

Ingiliz hukukunda; ana ve baba ile vasî arasında hị̧ bir fark gözetilmeksizin evlenmiye muvafakat etmemeleri halinde; mahkemeye müracaat olunabileceği kabul olunur. Mahkemenin bunlar yerine vereceği muvafakat üzerine evlenme icra edilir. (15). Fakat Ingiliz mahkemeleri; kanunen aranılan ana baba veya vasinin evlenmeye rıza göstermesi şartını; umumiyetle bir formaliteden ibaret olduğu şeklinde tefsir ederler ve muvafakat alunmadan aktedilen evlenmelerin butlan cihetine gitmezler (16). Yabanclar ana baba ve vasilerinin rızalarını almada da kendi Millî kanunlarına tâbidirler. Kanunun kendisine böyle bir mecburiyet tahmil ettiği yabancı; bu muvafakati almadıkça evlenme ehliyetini haiz sayllamaz. Lâkin İngiliz mahkemeleri burada şöyle bir tefrik yaparlar: Yabancinm kanunu yani Lex domicilii tarafindan aranilan bu muvafakata; o kanunda evlenmenin slhhatine tesir edecek bir mahiyet atfedilmişse; bu mu-

(12) Jenks: a short history of English law: Sa: 180 .

(13) Jenks: the book of English law. Sa: 283.

(14) N. Metya: Sa: 125 .

(15) Jenks: a digest of English civil law: Sa: 1054 yot.

(16) Cheshire: Sa: 229 vd. 
vafakat alınmadan aktẹdilen evlenme batıldır; lâkiı eğer aramılan bu muvafakat bir formalite mahiyetinde ise böyle bir formaliteyi aramyan bir memlekette muvafakat alımmadan yapılmıs bir evlenme muteberdir. Bir İngiliz mahkemesi Simonin dâvasi diye anılan bir davada, Ingilterede Fr. Mk 154 mucibince lâzımgelen muvafakat alınmadan evlenmiş olan iki Fransızın bu evlenmenin butlanı düvasını Fr. Mk. 154 üncü maddenin aradığı mufakatin bir formalite olduğundan bahisle reddetmişti (17).

Ikametgâh kanunu mucibince sarfınazar edilmesi mümkün olan bir muvafakate İngilterede evlenmenin aslî̀ şartlarmdan ziyade surî şartı nazariyle bakılır (18).

2 - Temyiz kudreti: Taraflarda, evlenme akdinin şumul ve mânasmı kavrıyacak bir kabiliyet aranır. Mk. 89 zá göre ancak mümeyyiz olanlar evlenmeye ehildir.

Millî kanun mahcurların hangi şartlar altında evlenebileceklerini tesbit eder.

Bizim kanunumuza göre mahcurlar; akıl hastası olmamak șariiyle, ancak vasilerinin muvafakatiyle evlenebilirler. Mahcurun; vasinin izin vermekten imtina1 halinde Mk. 404 mucibince vasi aleyhine sul mahkemesine muracaata hakkı olduğınu kabul edebiliriz.

Temyiz kudretini haiz olmıan bir kimsenin akteylediği evlenme mutlak butlanla batıldir Mk. 112/3.

3 - Akıl hastalığı: Mk. 89. Bir akıl hastasının evlenip evlenemiyeceği meselesi umumiyetle bir kamu intizamı meselesi olarak telâkki edildiğinden mahallî kanuna tâbidir. Bizim hukukumuza gööre akıl hastaları evlenemez. Binaenaleyh Türkiyede; kendi Millî kanunu müsait olsa bile; bir akıl hastasının evlenmesine müsaade edilmemek lâżm gelìr.

İngiliz hukuku da akıl hastalığının evlenmeye mâni teşkil eđeceğini ve böyle bir hastanın akteylediği evlenmenir: batıl (void marriage) olacağmı kabul eder. Ingiliz hukuku ayni zamanda evlenme anında sara ve zührevî (veneral disease) hastalıklara müptelà olanların da evlenmiyeceğini ve bu hastallkların bir nisbî butlan (Voidable) sebebi teşkil edeceklerini de öngörür (19).

B - EVLENMEYE MÂNI SEBEPLER: Prensip Millî kanunun tatbikidir. İngilterede ise mâni sebeplerden hısımlık ve diğer bütün

(17) Cheshire: Sa: 229 vd.

(18) Répertoire: cilt 6 : Sa: 40.

(19) Cheshire: Sa: 333. 
mutlak ve nisbî' ehliyetsizlikler Locus - regit - actum kaidesine tâbi tutulmuştur (20). Aslî şartlara ikametgâh kanununun tatbik prensibinne bu bir istisna teşkil eder. Medenî kanuṇlarin tâyin ettiği mânilerden bir kısmı hem evlenmenin icrasına mânidir ve hem de bu mânilerden birinin mevcudiyetine rağmen aktedilmiş evlenmenin butlaninı muciptir. Bunlara butlanı mucip sebepler (Empechements diriments, mutlak butlan sebeplèri) denir. Diğer bir kısm sebepler ise butlanı muci pölmıyan mâniler veya âdi sebeplerdir, bunlara (Empechements prohibitifs) denir. Bu sebeplerin mevcudiyeti evlenmenin icrasına mânidir, fakat bu sebeplerin mevcudiyetine rağmen aktedilmiş bir evlenme sonradan artık bunlara müsteniden feshedilemez (21).

Türk ve İsviçre kanunlarına göre evlenmeye mâni olan mutlak butlan sebepleri şunlardir:

1 - Evvelki bir evliliğin mevcudiyeti (çok evlilik, poligami): Bütün medenî cemiyetlerde tek bir kadınla evlenme mecburiyeti kabul edilmiştir; yalnız islâm hukukunun cari olđuğu memleketlerde poligamik evlenmeler mevcuttur. Çok evlilik her memleketçe bir kamu intizamı meselesi olarak telàkki edildiğinden; ecnebinin Millî kanunu böyle bir evlenmeye müsait olsa bile; bunun tekrardan evlenmesine müsaade edilemez.

Medenî kanunumuzda ikinci bir evliliği mutlak bir butlan sebebi olarak telâkki etmiş, ve sonradan aktedilmiş olan ikinci evlenmenin batıl olacağını Mk. 112/1 tasrih etmiştir. Türk ceza kanununda da bu prensibi teyideden bir hüküm vardır Ck. 237. Fakat medenî kanưn bu ikinci evliliğin $\mathrm{Mk}$. 114 deki şartlar altında sahi bir evlenmeye inkilâp edebileceğini de öngörür.

Fransız mednî kanunu da 147 inci maddesinde monogamik evlenme esasını kabul ettiği gibi, çok evliliği ağır cezaî müeyyedeye tâbi tutmuştur (22). Ingiliz hukuku da ikinci bir evliği mutlak butlan sebebi olarak telâkki eder.

Burada bir noktaya, müktesep haklara temas etmek lâzzamdir. Bir kimse yer yerde; gerek doğrudan doğruya kendi millì kanunu tarafindan ve gerekse bu kanuna uygun olarak verilen bir hükümle; iktisabetmiş olduğu durumu haiz olmalıdır (23). Binaenaleyh kendi kanununa uygun olarak yabancının memleketinde, aktetmiş olduğu

(20) Répertoire: cilt 6. Sa: 39.

(21) S. Gönensay: Sa: 24.

(22) Weiss: Sa: 284.

(23) Audinet: Sa: 234. 
poligamik evlenmeler böyle bir esası kabul etmiyen bir yerde de muteber olmal, ve onun kendi kanunlarma uygun olarak iktisab ettiği bu duruma her yerde hürmet edilmelidir. Bu prensip umumiyetle her memleketçe kabul ve tatbi kedilmektedir. Fakat ecnebilere münhasir olan bu haktan poligamik evlenmeyi kabul etmemiş devletler tabasi istifade edemez.

2 - Hısımlık: Âmme intizamına muhalif olmamak şartiyle Millî kanuna tâbidir. Yakın hısımlar arasında evlenme, aşağı yukarı her devirde tabiat kanunlarına ve ahlâka muhalif addedilerek menedilmiştir. Bununla beraber evlenmeye mâni hisımlık dereceleri hakkında muhtelif devlet kanunları arasında bir ahenk yoktur. Bazı memleketlerde pek uzak hısımlarla bile evlenme memnuiyetine rağmen, bazıları bu hususta çok liberal davranır. Bu memnuiyet hakkındaki kanun hükümleri daha ziyade sihhî sebepler ve evlilik birliğini s1yanet maksadiyle konmuş olduğundan, her memlekette kamu intizamından telâkki edilir; bunun için de evleneceklere daha müsait olan kendi Milli kanunlarmn tatbik edilmesine müsaade edilmez.

Bütün kanunlar; mutlak olarak düz hat üstündeki gerek kan ve gerekse sthrî hisımlarla her derecede evlenme memnuiyetini kabul ederler. Mk. 92/1, Mk. 112: IMk. M. 100: Fr. Mk. 161. İngiliz hukuku da böyle bi revlenmeye müsaade etmez.

Bizim kanunumuz civar hisimlar arasindaki evlenme memnuiyetini: kardeşlerle, teyze, hala, amca ve daylara: shrî hısımlar arasinda da evlilik nihayet bulmuş olsa bile kaytn baba ve analarla damat ve gelin ve karr ve kocanın yarım evlâtlariỵle evlenmelerine hasreder.

İngiliz hukuku bu hususta daha titiz davranrr. Civar ve shrî hısımlar arasındaki evlenme memnuiyeti her ikisine de şamil olmak üzere üçüncü dereceye kadardır, bu derece de memnuiyete dahildir. $\mathrm{Bu}$ memnuiyete rağmen yapılmıs evlenmeler bizirn hukukumuzda olduğu gibi orada da batıldır (24). Ingilterede hisımlıktan mütevellit mâniler diğer bütün mânilerde olduğu gibi Lex - loci'ye tâbidir.

Evlenmede en liberal davranan Almanyadır. Alman kanunu yeğen ile evlenmeye müsaade eder (25). Fransada böyle bir evlenme ancak bir dispansla mümkündür (26). Lâkin Türkiyede, bir alman kamu intizamı dolayısiyle yeğeni ile evlenemez. Böyle bir evlenme aktedilmiş olsa bile Mk. 112 mucibince batıldır.

(24) Jenks: a digest of English law: Sa: 1060 vd.

(25) N. Metya: Sa: 124.

(26) Weiss: Sa: 482. 
Hısımlıktan doğan memnuiyetleri iki kısma ayırmak mümkündür (27):

a) Mutlak memnuiyetler: Bunlarmn hiç bir suretle ortadan kalkması mümkün değildir. Bu mânilere rağmen aktedilmiş bir evlenme de Lex - loci mucibince daima batıldır. Bizim hukukumuzdaki h1sımlıktan mütevellit mânilerin hepsi mutlak mầnilerdir. Bunun yalnız bir istisnası evlâtlıkla evlenmeye dair olan mâniidir, evlâtlıkla evlenme halinde ,evlenme sahih bir evlenmedir; ancak evlâtlık rabıtası ortadan kalkar Mk. 121. Alman medenî kanununda da evlâtlikla evlenme hakkında ayni hüküm caridir (28).

b) Mutlak olmıyan ve bir dispansla ortadan kaldımlması mümkün olan müniler: Bu dispans devlet reisi veya papa tarafindan v́erilir (29). Amerikada boşanmış bir kadın eski kayın biraderiyle evlenebilir, halbuki Fransada böyle bir evlenme ancak devlet reisinin vereceği bir dispansla mümkündür Fr. Mk. 163.

Acaba bir dispansla ortadan kalkması mümkün olan bu gibi mâniler ecnebilere de tatbik edilmeli midir? Meselâ bir Almanın Fransada yeğeniyle evlenmesine müsaade edilmeli midir?

Bunun yabancilara tatbikine aleyhtar olanlar; alelâde idarî bir dispansla ortadan kalkmas imümkün bu gibi mânilerin kamu intizamundan addedilemiyeceğini ileri sürerler. Fakat böyle bir memnuiyetin yabancllara da uygulanmass lehinde olanlar ise weiss'e göre hakh olarak şöyle derler: Kanun koyucu bu gibi kimseler arasındaki evlenmeyi umumî olarak menederken, bu şahıslarm özel menfaatlarụdan ziyade âmmenin menfaatini göz önünde tuttuğu açıktır ki bu da dispansların kamu intizamiyle ilgili olduğunu gösterir. Bu sebeplerledir ki Fransada yeğeni veya kayin biraderi ile evlenmek isteyen yabancl, kendi kanununun müsaadesine rağmen dispans almak zorundadir $(30)$.

Audinet, mutlak olmiyan mânilerin âmme intizammdan olmadıklarını kabul eder (31). Bize de b ufikir daha mülâyim gelmektedir.

Evlenmeleri bir dispansla mümkün olan kimseler acaba böyle bir memnuiyet bulunmiyan bir memlekette evlenebilirler mi? Ev-

(27) N. Metya: Sa: 124.

(28) Arsebük: Sa: 651 .

(29) N. Metya: Sa: 124.

(30) Weiss: Sa: 482, 483: bu dispáns evleneceklerin mensu polduğu devletten değil. Fransız hükûmetinden alınacaktrr.

(31) Sa: 187 . 
lenme memnuiyetleri kamu intizamindan olduklarından bu soruya müsbet cevap vermek lâzımdur. Nusret Beyde ayni fikirdedir (32).

Din ayrılı̆̆ı, rrk ayrllı̆̆ 1 veya bazıı mezhepiere girmekten mütevellit mâniler diğer memleketlerde kamu intizamina muhalif addedildiklerinden tatbik edilmezler.

Ingiliz hukuku da bu gibi mânilerden müteveilit ehliyetsizliğin İngilterede nazara alınmıyacağını kabul eder (33).

Avusturya kanunu huristiyanla hristiyan olmyanlar arasmdaki evlenmeleri; Sırp kanunu da huristiyanlarla yahudiler arasındaki evlenmeleri meneder. Lâkin bir surbı̣n böyle bir memnuiyet bulunmıyan bir memlekette meselâ türkiyede bir yahudi ile evlenmesi pekâlâ mümkündür. Lâkin bu evlenmènin kendi memleketinde muteber addedilmesi çok şüphelidir.

Siyasî mahiyeti haiz olan mâniler: Meselâ hanedan mensuplarınin hariçten evlenmelerini meneden kanunlar hakkında da ayni prensip tatbi kolunur. Mamafih bu hususta iki nazariye vardir:

a) Siyasî mâniler istatü personel olduğundan Millî kanuna tâbidir. Ancak bu mâniler herkangi bir mẹmleketirı esas teşkilât kanunuxa muhalif olursa tatbik edilmezler. Umumiyetle kabul edilen görüş budur. Türkiyede de bu gibi mâniler hakkında bu nazariye tatbik olunur (34).

b) Bu memnuiyet bir istatü personel meselesi değil bir esas teşkilât meselesidir. Herhangi bir devlet bu mânileri tanımazsa diğer devletin esas teşkilâtına tecavüz etmiş olur. Bu nazariye ancak bazı monarzik devletler tarafından kabul edilmiști (35).

Bu siyasî mâniler meyanina bazı memurların ve askerierin evlenmeden evvel izin alma mecburiyeti veya muayven bir yaşı doldurmadan evlenme memnuiyetleri de girer. Alman medenî kanununun 1315 inci parağrafı mucibince asker kaçakları ve hattâ askerler ve bazı memurlar müsaade almadan evlenemezler (36).

Türkiyede de hariciye memurlarının ecnebilerle evlenmemeleri ve bu memurlarin evlenmeden evvel hariciye nezaretinden izin almaları hakkında 24/8/1325 tarihli bir iradei seniye vardır (37).

(32) N. Metya: Sa: 124: Devlet veya papantn vereceği dispans üzerine evlenmeleri mümküin olan kimseler hakkındaki bu mâniler diğer memleketlerde nazara alınmaz.

(33) Répertoire: cilt 6. Sa: 39.

(34) N, Metya: Sa: 123.

(35) N. Metya: Sa: 123.

(36) Nibayet: Se: 525 .

(37) Sicilli kavanin: cilt 16. Sa: $51 ; 25 / 6 / 927$ tarih ve 1154 No. It 
Ayni şekilde bilûmum muvazzaf zabitlerle askerî memurların 25 yaşım ikmal etmeden evlenmiyecekleri hakkında 929 tarih ve 1434 No. ll bir kanun da vardir. (38).

Böyle siyasî bir maksatla konmuş olan mânilerin diğer memleketlerde nazarı itibara alınmaması lâzımdır (39).

\section{EVLENECEKLERIN AYRI AYRI TABIIYETTE BULUNMA- LARI HALI:}

Bu vaziyette de prensip olarak her birisi kendi millî kanununa tâbidir. Fakat burada şöyle bir sual varit olabilir: acaba bu takdirde kadın evlenme ile kocasmin tabiiyetine gireceğinden; kadına da kocanin kanununun uygulanması yerinde olmaz $\mathrm{ms}$ ?

Bazı yazarlar bu fikri müdafaa etmektedirler (40). Cheshire'e göre taraflardan her birinin evlenme ehliyeti, ve evlenmenin sihhati evlilik birliğinin ikametkâhı kanununa (matrimonial domicil) tâbi olmalıdır; çünkü evlilik, hükümlerini ikametgâh olạrak seiçlen mahalde vücuda getirecektir. Evlilik birliğinin ikametgâhı kanunu da, evleńmenin akabinde kocanın ikametgâh olarak ittihaz edeceği mahaldeki kanundur (41).

Fakat bunlara karşı haklı olarak şöyle itiraz edilmektedir: Birlik, bilhassa vatandaşlık birliği ancak sahih ve muteber bir şekilde aktedilmiş bir evlenme neticesinde meydana gelir, evlenmenin aktine kadar da eşlerden her biri kendi tabiiyetini muhafaza eder. Binaenaleyh böyle bir birlik kurulmadan eşlerden birini diğerinin kanununa tâbi tutmak haksızlık olur (42). Zaten bir çok kanunlarda, evlenme ile kadinm kocasınin tabiiyetine geçmesini kabul etmez. Türk vatandaşlık kanununa göre (ecnebiyle evlenen Türk kadını yine Türk kalır» (43).

hariciye vekâleti memurin kanunu madde 13. Gerek iradei seniye ve gerekse kanun izin almadan evlenmenin müeyyidesi olarak hariciye memuriyetinden azil ve müstafi addedilmeyi gösterirler.

(38) Sicilli kavanin: Cilt 20, ve 939 tarih ve 3663 No.lt kanun. Bu kanun üçüncü maddesiyle bu kanumum, medenî $\mathbf{K}$. evlenmeye alair olan hükümlerine bir tesiri olmadiğını kabul eder. Şu halde kanunun bu hükmüne muhalif olarak evleneceklerin akitleri muteberdir. Yalntz muhalefet edene askerî $\mathbf{C}$. $\mathbf{K}$. 147 mucibince ceza görürler: Arsebük; Sa: 609 vd.

(39) Pillet: Sa: 555.

(40) Bu meyanda olmak izere bak Bartin Sa: 125.

(41) Cheshire: Sa: 219 vd.

(42) Weiss: Sa: 484, 485; Pillet: Sa: 558. vd; Audinet: Sa: 181.

(43) Fransiz kanunu da böyledir: T. Lombard. Sa: 37. 
Bu mesele hakkında şöyle bir teklifte de bulunulmuştur. Eşlerin şahıslarm himayeye dair olan hususlarda, her biri kendi Millî kanununa tâbi oĺmalıdır, yaş, kanunî mümessillerin muvafakati gibi; evlilik birliğinin himayesi için konmuş hükümlerde ise (ehliyetsizlik, evlenmeye mâni sebepler» gibi kadm kocanın kanununa tâbi olmalıdır, Lâkin böyle bir tefriki kabul pek de yerinde olmađiğı gibi (44) yeni bir çok ihtilâfların bilhassa "qualification" ihtilâflarının doğumuna da sebep olabilir; çünkü bir kanuna göre şahsî himayeye matuf hükümler, diğeri için böyle bir mahiyeti haiz olmıyabilir.

Macar kanununda bu görüşe yaklaşan şöyle bi rhüküm vardır: M 108: Yaş ve ehliyetin tâyininde eşlerden her biri kendi Millî kanununa tübidir; fakat diğer bütün hususlarda her biri diğerinin kanununda da aramılan şartları yerine getirmelidir (45).

İngilterede de; Ingilizle evlenecek, ikametgâhı hariçte olan bir yabancmun, kendi kanununa göre olan ehliyetsizliği; eğer bu yabancı Ingiliz hukukunun aradığı şeraiti haiz ise nazara alınmaz (46).

Apatritlerin evlenmelerinde tâbi olacakları kanun:

Apatritler. yahut haymatlozlar hiç bir devletin tabiiyetinde olmiyan vatansızlardır. Ilk umumî harpten ve bilhassa Rus ihtilâlinden sonra sayıları çok artmıştır. Bunların istatü personellerinin ve dolayısiyle evlenme ehliyetlerinin ikametgâh kanununa; ikametgâhlarımın mevcut olmaması halinde ise sakin bulundukları mahal kanunlarına tâbi olmaları umumiyetle kabul olunur. Fransa, Rus ve Ermeni mültecileri hakkında bu sistemi tatbik etrnektedir (47).

Haymatlozlarm istatü personelleri bakımmdan eskiden vatandaşı bulundukları kanuna tâbi olmaları, bazıları tarafından ileri sürülmüssse de bu görüş kabul edilmemiştir.

Birden ziyade milliyeti haiz olanlarm tâbi clacakları kanun: Muhtelif devletlerin vatandaşhk kanunlarının ayni olmaması ve biribirine zit hükümleri muhtevi bulunmaları dolayısiyle bir kimsenin ayni zamanda birden ziyade devletin vatandaşı olması mümkündür.

Armazon Carry "lette de change» adl 1 kitabında bu kimselerin poliçe hukukundaki ehliyetlerinin tâyini için iki halin göz önün-

(44) Audinet de ayni fikirdedir: Sa: 181.

(45) Audinet: Sa: 181 : 1894 tarihli kanun.

(46) Pillet: Sa: 556.

(47) Répertoire: cilt: 9. Sa:: 28. 
de tutulması icap ettiğini ileri sürer: Bize bu gibi kimselerin evlenme ehliyetinin de ayni suretle halli mümkün gibi görünüyor:

1 - Eğer bu gibi kimseler Lex fori (48) mucibince bu kanunun tabiiyetini haiz addedilebiliyorsa Lex fori tatbik edilmelidir.

2 - Eğer birden ziyade tabiyeti olan şahıs Lex fori mucibince; bu devlet tabiiyetini haiz değilse; kendisine fiilen haiz olduğu vatandaşltğın atfı. làzımgelir. Bu fiili vatandaşlık da ekseriyetle ikametgâh mahallî vatandaşlığıdır.

Bir takım yazarlar da haiz olunan tabiiyetlerden hangisi böyle bir şahsı ehil addediyorsa o kanunun tatbik edilmesi lehindedirler. Bizce bu son fikrin kabulü ihtilâfları çoğaltacak mahiyettedir.

\section{EHL.TYETIN ISPATI:}

Kendi Millî kanunlarına göre evlenme ehliyetini haiz olduklarinı ispat müstakbel eşlere düşer (49). Bunu ispat oldukça zordur; çünkü bu hususta eşlerin yalnız kendi Millî kanunlarının metnini ibraz etmeleri kâfi gelmez; Onlar ayni zamanda kanunlarmın arad1ğl bu ehliyeti haiz olduklarını da ispat mecburiyetindedirler. Bu hususun her türlü beyyine ile ispatına müsaade edilmelidir (50 - 51).

Türkiyede ilân yaplması için kendisine müracaat edilen evlendirme memuru; evleneceklerin evlenme ehliyetini haiz olup olmadıklarını veya evlenmelerine mâni bir sebebin mevcut olup olmadiğını tahkik zorundadır Mk. 99. Türkiyede yabanıılar ehliyetlerini her türlü vasitalarla ispat edebilirlerse de fiiliyatia bunun konsoloshanelerinden alacakları vesikalarla yapılması talep edilmektedir (52).

La Heye anlaşması M. 4 ehliyetin konsoloslardan alınacak vesikalarla veya herhangi bir şekilde ispat edilebileceğini kabul eder.

Alman ve İtalyan hükûmetleri temsilcilerini böyle vesikalar vermekten menetmektedir (53). Weiss, konsoloshaneler tarafindan verilen bu gibi vesikaların hatadan âri olamiyacağı cihetle, böyle bir vesikanın mevcudiyetine rağmen yabancı bir memlekette aktedilmiş

(48) Sa: 460 vd; yalniz burada tabiatiyle Lex foriden bahsedj'emiyeceğine göre bụ kanunun Lex Loci olması lâzımgelecektir. Așağıda geçecek bìtün lex forileriler bu sekilde anlaşılmalıdır.

(49) La Heye anlaşmasi: M. 4.

(50) Pillet: Sa: 567.

(51) Fransa adalet bakanlı̆̆ının 1831 tarihli bir sirküleri evlendirme memuriarına; yabancılarian doğum veya san ikamet mahalli idarî. makamlarundan alınmıs bir sertit.ka aramak mechuriyetini tahmil eder: Weiss: Sa: 484 .

(52) Répertoire: cilt: 7, Sa: 264. 
olan bir evlenmenin Millî mahkemeler tarafindan iptal edilebileceğini söyler (54).

\section{MILLI KANUNUN TATBIKINDE KAMU INTIZZAMI MESE- LESI: \\ Evlenmenin asiî şartlarına Milì kanunun uygulanması prensibi,} sık sık bir memleketin ahlâkî, içtimaî telâkkilerine, daha genel bir deyişle kamu intizamına aykırı olduğundan bahisle; ortadan kaldırilır. Amme intizamının evlenme sahasındaki rolì çok ehemmiyetlidir. Niboiyet'ye göre bunun önemi kamu intizammın mahiyet ve tatbik alanlarının her devletçe ayni şekild ekabul edilmemiş olmasindan ileri gelir. 1905 tarihli La Heye konferansinda kamu intizaminm tatbik sahasinda yeni bir sistem kabul edilmis ve her devletin; herhangi bir kanuna ihtiyaç kalmadan diplomatik yollarla, kendi memleketeinde nelerin ầmme intizammdan addedilmekte olduğunu bildirmesi kararlaştrrıımıştır (55).

Evlenmeye âmme intizamının iki şekilde müdahalesi mümkündür:

1 - Millî kanunun müsaade eylediği bir evlenmeye mâni olmak suretiyle: Millî kanunun, Lex loci tarafindan ahlâk ve fertlerin hürriyet ve serbestisi bakımından çok önemli sayılan bazı kaidelere aykırı hükümleri bulunması halinde kendini gösterir. Bu kaideler; halefet suretiyle aktedilmiş bir evlenme o memlekette tamamiyle bir iskandal addolunur (56).

Böyle bir evlenme akit mahallî kanununca batıldır; üçüncü şahıs vaziyetinde olan devletler bunu sahi olarak taynup tanımamakta muhtardrrlar. Millî kanun nazarmda ise bu evlenme muteberdir. Her Devlet âmme intizamına muhalif olan aşağıđaaki evlenmelere; Millî kanunun müsaadesine rağmẹn mümanaat edebilir:

a) Bigami: Her yerde kamu intizammdan telâkki olunur; ve Millî kanunun tatbikine müsaade edilmez. Meselâ bir Misırh Türkiyede ikinci bir defa evlenemez.

Burada şöyle bir sual bahis mevzuu olabilir: kendi memleketi kanunlarına göre usulü dairesinde boşanmış bir yabancı, boşanma

(53) Weiss: Sa: 485.

(54) Weiss: Sa: 485.

(55) Niboiyet: Sa: 543.

(56) İtalyan Kanunu M: 102 de bunu açkça göstert: İtalyadaki yabancılar evlenme mânileri hakkında yerlilerin tâbi oldukları kaidelere uymak' zorundadirlar. 
memnuiyeti olan bir yerde eşinin sağlığında tekrardan evlenebilir mi? Fransız yargitayı Fransada boşanma memnuiyeti olduğu zamanlarda (57) buna 1860 tarihinde müsbet cevap vermişti (58).

Fakat buna rağmen 1920 de bir Fransız mahkemesi, Fransada usulü dairesinde boşanmıs bir fransızın; o zamanlar boşanma memnuiyeti olan Ispanyada; ikinci defa aktetmiş olduğu bir evlenmenin batıl olduğuna karar vermişti. Pillet'in de işaret eylediği gibi bu karar şayan hayrettir. Çünkü boşanma memnuiyeti olan bir memlekette böyle bir evlenme belkide kamu intizamı gaygusuyla batı addolunabilir. Fakat böyle bir memnuiyet kabul eylemiş olan bir memleket vatandaşının akteylediği bir evlenmenin bilhassa kendi memleketinde batıl olduğuna hükmedilmesi herhalde hiç de doğru olmasa gerektir (59).

Bizce; boşanma memnuiyeti olan bir memlekette, bunu kabul etmemiş ve usulü dairesinđe boşanmiş bir devlet vatandaşının tekrardan evlenmesine müsaade edilmemesi bile yerinde değildir. Çünki her devlet, müktesep haklara bilhassa bunlar usulü dairesinde kazanılmışsa riayet etmek zorunđadır (60).

b) Hisımlıktan doğan memnuiyetlere ki bunlara yukarıda temas etmiştik.

c) Zina yapmış olan eşin şeriki cürmiyle evlenmesi ile eşlerden birinin hayatına kastetmiş olanla diğer eşin evlenmesi bazı memleketlerde intizamı âmmeden telâkki edilir ve Millî kanunun müsaadesine rağmen böyle bir evlenmenin aktedilmesine müsaade edilmez; aktedilmiş böyle bir evlenmede Lex loci mucibince batıl sayılır.

Zinada bulunanla evlenme memnuiyetini A M K. 1312 parağrafiyla kabul eder, bununla beraber bu memnuiyetten muafiyet istihsali mümkündür (61),

d) İddet müddetleri: tekrar evlenmek isteyen dul veya boşanmış kadınlara tahmil edilen bekleme müddetleridir. Intizam âmmedendir, çünkü bütün yazarların da kabul ettiği gibi bu müddetler nesebin sıhhati bakımından konmuşlardır (62).

(57) Audinet: Sa: 185.

(58) Fransada boșanma 1816 tarihli kanumla cocte civilden çikarilmışsa da 1884 tarahli kanunla tekrar iade olunmuştur: Weiss: Sa: 480.

(59) Ayni fikir: bak: Weiss: Sa: 481 vd.

(60) İlk evlitiğin ortadan kalkıp kalmadığını tâyin edecek kanun yabancintn Millî kanunudur: Aưdinet: Sa: 187.

(61) Asrebük: Sa: 628.

(62) Weiss: Sa: 981; N. Metya: Sa: 124; Audinet: Sa: 188. 
Mk. 95. Kadına boşanma veya ölüm tarihinden itibaren 300 günlük bir bekleme müddeti tâyin eder. Bu müddetin $95 / 2$ de gösterilen hallerin sübutu halinde ortadan kalkması mümkündür.

A M K. 1313 üncü parağrafiyle kadına 10 aylık bir bekleme müddeti tahmil eder (63). Fr. Mk. de M. 228 ile 300 günlük bi riddet müddeti kabul eder Weiss bu müddetin Fransada evlenmek istiyen yabancı kadına da şamil olması lâzımgeldiğini söyler (64).

Ayni suretle bir ecnebi kendi kanununda böyle bir müddetin mevcut olmamasına rağmen Türkiyede bu müddetlere riayet zorundadır; fakat şu var ki bizim kanunumuz bu müddetlere uyulmadan aktedilen evlenmeleri batıl saymadığından böyle, bir evlenme Türk kanunu nazarında muteberdir. Hariçteki bir türkün de akit mahallî kanunưn iddet müddeti hakkındaki hükümler mutlak bulunmadı̆̆ hallerde Mk. 95 muhalefetle akteylediği bir evlenmenin Türkiyede muteber addi lâzımdır.

A. Kemal; iddet müddeti Millî kanuna tâbi iše de bu kaydın mutlak olduğu memleketlerde, neseb işleri umumî intizama ve ahlâka tâbi meselelerden sayıldığı cihetle; Millî kanurın daha kısa bir müddet tâyin etmiș olması halinde bu kanun yerine Lex loci'nin tatbik olunacă̆ını kabul etmektedir (65).

2 -. Millî kanunun müsaade etmediği bir evlenmenin icrasını mümkün kılma suretiyle;

a) Millî kanunun, đin, urk ayrılığı bakımından koyduğu mâniler Lex - loci tarafından nazarı itibare alınmaz, meselâ bir Avusturyalı, Millî kánununun memnuiyetine rağmen 'Türkiyede hıristiyan olmıyan bir şahısla evlenmesi pekâlâ mümkündür. Seine mahkemesi, bir sırbın Fransada bu şekildeki bir evlenmesinin sahi olduğuna karar vermişti (66).

b) Boşanma yasağı olan bir memleket tebiasının; böyle bir memnuiyet olmiyan bir yerde tekrardan evlenip evienemiyeceği meselesi münakaşalıdır: Boşanma memnuiyeti; böyle bir yasak bulunmiyan bir memlekette kamu intizamından telâkki edilerek boşanmış kimsenin yeniden evlenmesine müsaade edilmelidir. Fałsat boşanma; Millî kanun ve Lex foriye tâbi olduğundan, fiilen böyle bir kimsenin

(63) Arsebük: Sa: 619.

(64) Weiss: Sa: 482 .

(65) Sa: 4525.

(66) T. Healy: Sa: 484. 
boşanmasina ve dolayısiyle evlenmesine imkân olamıyacakttr (67).

c) Dinî tarikatlara girme, ile, siyasî, mânilerin akit mahallî kanununca, nazara alınmıyacağını görmüştük. Bu mânilerden birinin mevcudiyetine rağmen aktedilen evlenme, Lex - loci'ye göre muteber, fakat millî kanun nazarinda batıldır. Diğer devletler bu evlenmeyi taniyıp tanımamakta muhtardirlar. Bu keyfiyet kanunlarının böyle bir memnuiyeti koymuş olup olmamasına göre değişeceğinden ortaya yeni yeni kanun ihtilâfları çıkacaktır.

\section{LA HEYE ANLAŞMASININ ASLÎ ŞARTLAR HAKKINDAKİ HÜKÜMLERI:}

La Heye anlaşması; 1902 de evlenmeden doğan kanun ihtilâflarının halli için garbî ve cenubî Avrupa devletleri arasında aktedilmişti (68). Bu mukavelename birinci maddesinde Millî kanunun sarih olarak başka bir kanuna atıf yapmadığı hallerde evlenme hakkı (droit de contracte mariage) müstakbel eşerin Millî kanunlarına göre düzenlenir» demekte; ve bu suretle ehliyet ve evlenmeye mâni sebeplerin Millî kanuna tâbi olduklarını tasrih etmekle beraber atfa da yer vermektedir. Alman meriyet kanunun 27 inci maddesinde atfı kabul eden şöyle bir hüküm vardır: "Evlenmenin inikadı taraflarm mensup olduğu Devlet kanununa tâbidir, fakat bu devlet kanunu mucibince Alman kanununun uygulanması lâzımgelirse bu son kanun tatbik edilirn (68 a).

Türkiyede ikamet eden bir İngilizin burada evlenmek istediğini farzedelim: Bizim sistemimize göre ehliyet bakımından kendi kanununa tâbidir; halbuki İngiliz kanunu ehliyetin Lex - domiciliye tâbi tutarak Türk kanununa atıf yapar, Türk hukuku da birinci derecedeki atfı kabul ettiğinden onun tatbik edilmesi lâzımdır $(69,70)$.

(67) 1330 tarihli muvakkat kanun M. 4; Boşanma ve ayr1lktan doğan kanun ihtilâflar: O. Berki: Adliye ceridesi 1945 Ekim Sa: 976; N. Metya: Sa: 133.

(68) Bu anlaşma Fransa, Almanya, Avusturya-Macaristan, Belçika, İspanya, Italyan, Holanda, Portekiz, Romanya, İsveç, İsviçre, Lüksenburg, arasinda imzalanmıştı.

(68a) Audinet: Sa: 179 .

(69) M. R. Sevik, atfin hatta münhasiran istatï personel meselelerinde bile kabulünǜn doğru olmryacağı kanaatindedir: Sf: 345 ; Duxdinet'de atfın aleyhindedir. Sa: 179 .

(70) Y. Karayalçın, Türkiyede D. H. H. ile uğraşantarın çơ̆unun bir dereceli atfın kabulü lehinde göründükklerini söyledikten sonra atfi kabul eden 
Acaba bu madde ile ikinci derecedeki atıf da kabul olunmuş mudư? Meselâ ikametkâhı Fransada olan bir İngilizin Türkiyede evlenmesine tatbik edilecek kanun hangi kanundur? Türk kanunu İngiliz kanununa, bu kanunda ikametgâh kanunu olan Frasız kanununa atıf yapmaktadır. Böyle bir vaziyet karşısında nasıl bir hal çaresinin kabulü lâzımdır?

Íki dereceli atıfta; tatbikı icabeden kanun Lex - fori (Lex - loci) den başka bir kanundur. Bu vaizyette yabancıları kendi kanunlarımn himayesinden daha fazla bir himayeye tâbi tutmaya mahal olmadığından bizce doğrudan doğruya Lex fori binnetice misalimizde Türk kanunu uhgulanmalıdır. Zaten doktrinde atfın kabul edilip edilmemesi meselesi çok münakaşalı olduğu gibi aleyhinde bulunanlar da pek çoktur (71).

Pillet; konferansın hazırlayıcı malzemesinden anlaşılacağı üzere birinci maddedeki bu kaydm yalnız atfı ihtiva etmediğini, ayni zamanda İsviçre gibi Millî kanuna sadık kalmakla beraber kendi vatandaşları için akit mahallî aknununun tatbikine de yer veren bir devlet tebeasınin; bu suretle Lex loci'ye uygun olarak akteylediği bir evlenmenin diğer âkit devletler tarafından da sahih olarak kabulünü, derpiş ettiğini söyler (72).

Birinci madde vasfa (qualification) na da temas etmektedir (73). Evlenme hakkn ne demektir, bundan ne anlaş̧lmak lâzımdır? Çünkü bu mefhum içine hem medenî hukuk tarafından aranılan ehliyet ve konulan mâniler, ve hem de diğer bazı siyasî mülâhazalarla konmuş olan mâniler de girebilir (74). Netekim Almanya ile Fransa ve Belçika arasında çıkan böyle bir vasıf ihtilâfından dolayıdır ki bu son iki devlet 1z14 de anlaşmayı feshettiklerini ihbar (dénoncer) etmişlerdi (75).

La Heye anlaşması yabancıların evlenmesine mâni sebepleri iki kısma ayırır: Birinci kısımdaki mâni sebepleri üç grupta toplamak mümkündür M. 2/1; Akit mahallî kanunu kendi hükümlerine muhalif olan bu evlenmeleri menedebilir:

bir de yargıtay kararına işaret etmektedir: Adliye cerídesi sayı 1945 Kasım Sa: 1051.

(71) Niboyet: Sa: 973 vd; Audinet: Sa: 179.

(72) Sa: 509 .

(73) Qualification herhangi bir müessesenin hukukî mahiyetini tayindir: Niboiyet Sa: 496.

(74) Niboiyet bu bakımdan da bu anlaşmayı tenkit etmektedir.

(75) Niboiyet: Sa: 521 vd. 
1 - Hisımlıktan mütevellit mutlak mâniler;

2 - Eşlerden birinin zinası dolayısiyle bozulan evlenmelerde, zinada bulunan eşin şeriki cürmiyle evlenmesine mâni olan hükümler.

3 - Eşlerden birinin diğer eşin hayatına kastedenle evlenmesine dair olan mâniler.

Lâkin bu mâniler ancak mutlak oldukları nisbette yabancilara tatbik olunur. 2 inci maddede nazarı dikkati celbeden şöyle bir hüküm vardır: "Bu mânilerin mevcudiyetine rağmen evlenmenin; Millî kanun veya atıf yapılan kanun tarafindan sahih olarak kabulü halinde, akit mahallî kanununca da batıl addedilmiyecektir". Bu madde ile kamu intizam telâkkisine bir yenilik getirilerek vatandaşlar için mutlak butlan sebebi teşkil eden mâniler yabancilar için âdi birer mâni sebep mahiyetini almaktadır.

Ikinci kısımdaki mânileri de iki grupta toplamak mümkündür: M. $2 / 2$.

1 - Akit mahallî kanununca kabul edilmiş dinî mânilere (Empechement $d$ ' ordre religieux muhalif evlenmeler.

2 - Çok evlilik.

Bu mânilere mutlak mâniler diyebiliriz, çünkü ikinci madde mucibince bunlar evliliğin Lex loci mucibince butlanını icabettirir.

Üçüncü madde Millî kanun veya atıf yapılan kanunư dinî sebeplere müsteniden menettiği evlenmelere Lex loci'nin müsaade edebileceğini kabul eder. Yabancl devletler böyle bir evlenmeyi taniyıp tanımamakta ayni maddenin ikinci fikrasiyle serbesttirler. Bu evlenmenin Millî kanununca muteber addedilip edilmiyeceği her halde çok şüphelidir.

La Heye anlaşması evlenmeden doğan kanun ihtilâflarmı yeknesak bir şekilde halletmiştir denilemez. Pillet de mukaveleyi; bütün bu yukarda temas ettiğimiz hükümlerinin fiiliyatta birçok güçlüklere ve hoş olmıyacak vaziyetlere meydan vereceğinden dolayı tenkit etmektedir (76).

La Haye anlaşmasmun tatbik sureti: $\mathrm{Bu}$ husus sekizinci maddelerle tesbit edilmiştir. $\mathrm{Bu}$ maddelere göre:

1 - Bu anlaşma âkit devletlerin yalnız Avrupa kıtastndaki toprakilarında tatbik edilecek.

2 - Bu mukavele, âkit devletler topraklarında icra kılınan ve

(76) Sa: 572 . 
taraflardan en az biri âkit devletlerden birine mensup olan evlenme akitlerinde cari olacak.

3 - Akit devletlerden birine ait olmıyan bir kanunu tatbik mïkellefiyeti âkitlere tahmil edilmiyecektir.

Görülüyor ki bu şartlarda ihtilâfların hallinde ikili bir sistemin doğumuna sebebiyet verecek mahiyettedir.

\section{EVLENMENIN SURİ SARTLARI}

Evlenmenin surî şartları taraflarm rıalariyle inikat edecek olan evlenme akdinin; sahih bir evlenme mahiyetini haiz olabilmesi için riayeti mecburî şartlardır. Lombard'ın da işaret ettiği gibi evlenmeye tam mânasiyle ruzaî bir akit göziyle bakılamaz, evlenme akdi; daha ziyade şekle bağlı bir akit mahiyetini haizdir (77). Çünküi muteber olabilmesi için akte üçüncü bi rşahıs olan resmî bir makamm iştiraki lâzımdır Mk. 109 (78).

Evlenme akdinin tâbi olduğu şekil bakımından devletleri 4 gruba ayırmak mümkündür:

1 - Medenî evlenme ile dinî evlenmeyi biriłjinden tamamen ve açıkça ayıran devletler: Türkiye, Fransa, Almanya, İsviçre gibi.

2 - Dinî ve medenî evlenmeyi ayni zamanda kabul eden devletler: Ingiltere ve İtalyada; bu iki evlenme șekli ayni zamanda kabul edilmiştir, evlenecekler bu iki şekilde birini intihapta serbesttîrler. Ispanya, Avusturya ve Portekizdeki vaziyet bundan biraz daha farklıdır. Oralarda katolik olanlar için dinî nikâh. katolik olmıyan için de medenî nikâh kabul olunmuştur.

3- Evlenme için dinî merasim icrasını mecburû̀ tutan yani evlenmeyi dinî bir akit olarak kabul eden devletler: Yugoslavya, Bulgaristan, Yunanistan, İsveç gibi.

4.- Evlenmeyi tamamen rizaî bir akit (solo - consansu) sayan ve evlenme için hususî bir şekil mecburiyeti koymıyan devletler: Birleșik Amerika devletlerinden bazılarında vaziyet böyledir (79). Rusyada; 1920 tarihli kanun, evlenme için hususî bir şekil kabul etmemisti, evlilik taraflarm ruzasiyle yapilan bir tescille tezahür edebileceği gibi tescilsiz de meydana gelebilir. İskoçyada hem rızấ evlenme ve hem de hususî bir şekle tâbi olarak yapılan evlenmeler

(77) Lombard: Sa: 42; Arsebük: Sa: 561; Jenks: the book of English law: Sa: 74 .

(78) Evlendirme memuru... taraflarin muvafakat cevaplari üzerine evlenmenin her ikisinin de rzzasiyle kanunen aktedilmiş olduğunu söyler.

(79) Newyork devletinde evlenme şekli birdir; Pihlist: Sa: 544. 
vardır. İskoçyadaki rızaî evlenme tarafların şahitler önünde rızalarmı açıkça beyan etmeleriyle vücut bulur. Fakat \$856 dan beri bu şekilde bir evlenme için kanunen İskoçyada 3 haftalık bir ikamet şartı konulmuştur (80).

Surî şartlara prensip olarak Locus Regit Aktum kaidesi tatbik olunur. Bu presnip bütün Devletler tarafınđan kabul olunmuştur. Fransa ve İsviçre kanun koyucuları sarih olarak vatandaşlarımun ecnebi memleketlerde bu kaideye uygun olarak aktedecekleri evlenmelerin muteber olduğunu tasrih ederler: Fr. Mk. 170/1, İsviçre meriyet kanunu M. 59/7 f.

İngiliz hukuku da evlenmenin suri şartlarının I. R. A. kaidesine tâbi tutar; lâkin Ingilizlerin; yabancı bir memlekette kendi millî kanunlarına uyarak akdettikleri evlenmeleri de muteber sayar. Fakat bunu evlenilecek mahallin, evlenme akdini tanzim eden kaideleri bulunmaması veya evlenme şeklinin Hiristiyaolığın aradığı şekilden hariç bir şekil, olması (İs a non chistian nature) haline hasreder (81).

Şekil şartlarına riayetsizliğin müeyyidesini Lex loci tâyin eder.

Türklerin de yaabncı memleketlerde o memleket kanunlarına uygun olarak akdettikleri evlenmeler muteberdir (82).

Evlenmenin suri şartları bakımından bizim hukukumuz şu formaliteleri arar:

A) Ilânlar :Illândan maksat ,evleneceklerin evlenme kararlarinı alâkadarlara bildirmek ve alâkadarların kanunî sebeplere müsteniden itiraz haklarmı istimale meydan vererek evlenmeye bir mârí mevcutsa bunu meydana çıkarmaktır (83). İlânın bu mahiyeti göz önünde tutulursa onun da L. R. A. kaidesine tâbi olması lâzımgeldiği kolaylıkla anlaşılabilir. Çünkü evlenmeye mâni sebeplerin ekserisinin kamu intizammdan telâkki edilerek butlan sebebi teşkil ettiklerini yukarıda görmüştük.

İlânın bu karakterini nazara alan bazı kanun koyucuları, vatandaşlarinm L. R. A. kaidesine uygun olarak yabancı memleketlerde akdettikleri evlenmeleri muteber saymakla beraber; bu evlenmelerin icrasından evvel bir kere de kendi memleketlerinde ilân edilmesini isterler: Fr Mk. 170; Belçika, Macaristan ve İtalyan kanunlam

(80) A. Kemal: Sa: 4530; cheshire: Sa: 325.

(81) Cheshire: Sa: 328; Jenks a diger of English law: Sa: 1059.

(82) M. R. Sevig: Sa: 363 .

(83) S. Gönensay: Sa: 32. 
böyle bir ilânın kendi memleketlerinde de yapılnasını arıyan kanunlardır. İspanya ve isvę̧ gibi bazı memleketler; kendi topraklarmda yabanclların akdedecekleri evlenmelerin; yabancinın mensup olduğu devlette de ilân edilmiş olmasını isterler. Ispanya kanunu M 91 bunu İspanyada iki seneden az bir zamandanberi yerleşmiş olan yabanclara; İsveç kanunu ise bu formaliteyi, ecnebinin Millî kanunun böyle bir ilân aradığı hallere hasreder (84). Şu halde bir Fransız; İsveçte kendi memleketinde evlenmenin ilân edilm:iẹ olduğunu ispat etmedikçe evlenemez.

Yabancının tâbi olduğu kanunun aradığı bu fơrmalitenin yapılmamış olmasının müeyyidesi nedir? İlân yapılmadan aktedilmiş olan evlenme batıl mı addedilmelidir? Bu mesele; Fransada çok münakaşayı mucip olmuş, nihayet bunun bir butlan sebebi olmıyacağı kabul edilmiştir. Belçika kanun koyucusu bu neviden bir tereddüde son vermek maksadiyle 170 incì maddeyi 1882 de: «ilânm Belçikada yapılmamış olmasının bir butlan sebebi teşkil etmiyeceğin şeklinde tâdil etmişti (85).

Medenî kanunumuzun 98 inci maddesinden, Türklerin hariçteki evlenmelerini Türkiyede ilân ettirmeleri lâzımgelciğgi mânası çıkarrlamaz (86).

İngiliz hukuku da evlenmenin ilân edilmesi lâzımgeldiğini kabul eder. Sivil evlenmelerde bu ilânın yirmi bir gün müddetle (superintendent register) ofisinde asllı kalmasın, dinî evlenmelerde ise ilânın üç pazar kilisede dinî merasimden sonra okunmasını öngörür (87),

Lex loci tarafından aranılan ilân yapilmadan ’cra edilen evlenmeler muteber midir? Bu soruya cevap verebilmek için şöyle bir tefrik yapmak lâzımgelir:

a) Eğer akit mahallî kanunu, ilânsız yapılan evlenmelerin batıl olmıyacağım tasrih etmişse; Mk. 123 gibi; bu evlenme o memlekette muteber olduğu gibi yabancmın kanunu böyle evlenmeleri batıl saymamışsa orada da muteberdir. Gerek akit mahalli ve gerekse Milli kanun mucibince sahih olan bir evlenme de her yerde sahih olarak kabul olunur (88) Binaenaleyh Türklerin; köyle bir memle-

(84) Audinet: Sa: 194.

(85) Audinet: Sa: 194.

(86) M. R. Sevig: Sa: 363 .

(87) Jenks; a digest of English law: Sa: 1050 ve 1052.

(88) Cheshire: Sa: 233. 
kete ilân yapmadan akdettikleri evlenmelerin de Mk. 98 mucibince muteber addi lâzımdir (89).

b) Fakat eğer yabancının Millî kanunu ilânı evlenme akdinin esaslı unsurlarından addederek, ilânsız evlenmeleri batıl saymışsa evlenme yalnız orada hükümsüzdür. La Heye anlaşmasının beşinci maddesinin üçüncü fıkrası da ayni hükmü havidir: "Millî kanunun ilânlar hakkındaki hükümlerine riayet edilecektir, fakat bu ilânların yapılmamı şolması, evlenmenin ancak hükmüne riayet edilmemiş olan memleketler butlanını icap ettirir.

B) Evlenme akdinin inikadı için yapılmas ılâzımgelen formalite: L. R. A. kaidesine tâbidir. Lâkin bu konuda dinî evlenmeyi kabul etmiş devletlerle medenî evlenmeyi kabul etmiş olanlar arasında bir ayırma yapmak lâzımdır:

1 -. Medenî evlenmeyi kabul eden devletler; daha liberal davranarak vatandaşlarının, mahalîi kanuna uygun olarak akdettikleri evlenmeleri muteber sayarlar; hattâ bu evlenme dinî bir şekilde aktedilmiş olsa bile.

Çünkü bu memleketlerde evlenme akdinin tâbi olduğu usul doğrudan doğruya bir şekil meselesi addolunur.

Dinî ve medenî nikâha ayni kıymeti atfeten memleketlerden birinde bu iki şekilden birine uygun olarak vücut bulmuş bir evlenmede muteberdir. Weiss ve Niboiyet'de bu fikirdedir (90). O halde bir Türkün İngilterede din' şekild eaktetmi şolduğu evlenmenin memleketimizde muteber olması lâzım gelecektir. Weiss ve Audinet solo-vonsansu evlenmeleri kabul etmiş bir devlette bu şekle uyarak iki Fransızın yapmış olduğu evlenmenin de muteber olacağ 1 fikrindedirler, fakat Weiss bu şekildeki bir evlenmenin ispatmın müşkül olduğunu da ilâve eder (91).

L. R. A. kaidesine muhalif olarak yapılmıs olan evlenmeler batıldır. Mogolistanda bir Belçikalı papas tarafından aktedilmiş bir evlenme Paris mahkemesi tarafından bu sebeple iptal edilmiştir (92).

Ingilterede; bir İngiliz kadıniyle evlenecek bir yabancı erkeğin; evlenme akdi esnasinda, bu evlenmenin yabancının memleketince tanınıp tanınmıyacağını ve erkeğin kaunu mucibice yapılması icabede formalitelerin yapılıp yapılmadığını ve Hariciye vekâletinden

(89) M. R. Sevig: Sa: 364.

(90) Weis: Sa: 487, Niboyet: Sa: 273.

(91) Weiss: Sa: 486, Audinet: Sa: 191.

(92) Neboiyet: Sa: 273 . 
(secratary of stade) izin alını alımmadığını, evlendirme memuru tahkik mecburiyetindedir (93).

İngiliz hukuku L. R. A. kaidesine göre aktedilen evlenmeleri, monogomiyi kabul etmiş bir memlekette aktedilmiş olmaları şartiyle muteber sayar. Westlake, hattâ daha ileriye gidejek poligomik bir evlenmeye İngilterede sahih bir evlenme nazariyle bakılamıyacağını da söyler (94).

Portakiz hükûmeti de vatandaşlarının L. R. A. ma tâbi olarak aktedecekleri evlenmeleri bu evlenme şeklinin Portekiz kamu intizamına muhalif olmaması şartiyle tanır (95).

İsviçrede yabancı erkeklex meriyet kanununun $59 / 7 \mathrm{c}$ mucibince ikamet ettikleri kanton hükûmetinden alacakları müsaade üzerine evlenebilir, böyle bir müsaade; yabancmm mensup olduğu devletin bu evlenmeyi sahih olarak tanıyacağını bildirmiş olması halinde; verilmemezlik edilemez. İkamtegâh sahibi olmıyarı yabancılar için de ayni hüküm caridir, yalnız müsaadeyi verecek makam, evlenmenin iera edileceği kanton hükûmetidir. Kadınlar için böyle bir kayit yoktur.

Yábancı, bir memlekette, Millî kanunun aradı̆̆ı şekle uygun olarak aktedilmiş bir evlenme muteber midir? Bundan L. R. A. kaidesinin mecburî veya ihtiyarî olup olmadığı meselesi ortaya çlkar. Bu mesele çok münakaşalıdır. Eğer evlenecekler ayrı ayrı tabiiyette iseler mesele yoktur, ancak L. R. A. kaidesine göre evlenmelidirler. Fakat ayni tabiiyette iseler ne olacaktır? Eğer bu kaideye mecburi bir mahiyet atfedilirse yabanciların ancak akit mahallì kanununa uygun olarak aktetikleri evlenme muteber oddedilecektir. Isviçre kanun koyucu L. R. A. nın bu mahiyeti haiz olduğunu kabul ederek meriyet kanununun 59/7 c fıkrasiyle, İsviçredeki; evlenmelerin inikadında riayeti lâzım gelen şekilin İsviçre kanunınun kabul ettiği şekil oiduğunu tasrih eder. Bazılara L. R. A. nın ihtiyarì bir karakteri olduğunu kabul ederler; meselâ Alman hukukiu, yalnız hariçte yapilacak evlenmeler için L. R. A. kaidesine bu karakteri tanır (96).

Fransız mahkemeleri bu kaidenin mecburî olduğunu kabul ederler (97).

(93) Cheshire: Sa: 327.

(94) Chestire: Sa: 316, 319.

(95) Répertoire cilt IX: Sa: 31.

(96) Répertoire: cilt IX: Sa: 33.

(97) Répertoirl: iclt 9. Sa: 33; halbuki Lombard Franstz Jurispridansinn buna fakültatif bit katakter atfettiğini söyler. Sa:42. 
Bu kaideye mecburî (obligatoire) mahiyeti atfetmenin daha doğru olduğu kanaatindeyiz, zaten bu bizim hukukumuzun ruhuna da daha uygundur $(98,9 z)$.

Weiss, Pillet, Von Bare gibi yazarlar ise, L. R. A kaidesinin evlenme bahsinde de ihtiyarî (facultatif) bir mahiyeti olduğunu ileri sürerler. Bununla beraber Audinet bu kaidenin mecburî (Obligatoire) oluşunu kabul edenlerin daha fazla olduğunu söyler (100).

Audinet bu meselede şöyle bir hal çaresine varyor. Yabancl bir memlekette ikamet edenler L. R. A. kaidesine tâbi olmak zorundadırlar; bu memlekette ikamet etmeyip te sakin olanlar kendi Millî kanunlarma göre de evlenebilírler (101).

Weiss, Millî kanunları kamu intizamına muhalif olmamak şartiyle yabancrların bu kanuna uyarak aktettikleri evlenmelerin muteber addedilmesi lâzımgeldiğini beyan eder (102). Fakat yabancınun Millî kanununun dinî evlenmeyi kabul etmesi halinde, Fransada böyle bir evlenmenin muteber olmyacağını da ilâve eder.

2 - Dinî evlenmeyi kabul eden Devletler: Bu devletler evlenme akdi için icrası lüzumlu merasimi evlenmenin aslî şartlarından telâkki ederler; bu sebep dolayısiyle de vatandaşlarının yabancı bir memlekette Lex - loci'ye göre yapmı̧ oldukları evlenmeyi muteber saymazlar.

Osmanlı imparatorluğu zamanmda, gayri müslim teba arasındaki evlenmeler dinî̂ idi. Bir Ermeninin ṫtalyada mahallî şartlara uygun olarak yaptığı bir evlenmenin muteber olup olmıyacağı meselesi uzun müddet münakaşa konusu olmuştu. Hariciye nezareti $L$. R. A. kaidesine uygun olarak yaplan böyle bir evlenmenin muteber olduğuna karar vermişti; şûrayı devlet ise jki taraflı bir yol takip ederek Türklerin gerek mahallî şartlara ve gerekse Millî şartlará uyarak yabancı memleketlerde akdettikleri evlenmeler muteberdir demişti (103).

(98) Ceza kanunumuz evlenme kâğ1đi ibraz edilmeden evlenmenin dinî merasimini icra edenlerle ettirenleri ceza müeyyidesi altıra almıştır. M. 237. Zaten evlendirme memuru önünde aktedilmemiş bir evlenmeye bizim hukukumuzda yok evlenme (matrimonum non existens) nazariyle bakılar: $\mathbf{H}$. A. Göktürk: Sa: 285.

(99) N. Metya: Sa: 132.

(100) E. Audinet: Sa: 201; Weiss: Sa: 479.

(101) Sa: 204.

(102) Sa: 496.

(103) N. Metya: Sa: 122. 
Dinî nikâhı kabul eden devlet vatandaşları için yapılacak şey L. R. A. kaidesine uyarak evlendikten sonra, bir de dinî nikâh yaptırmaktır. Türkiyede dinî merasim ancak medenî nikâhtan sonra yapılabilir (104). Fakat böyle dinî bir merasim yapılmamış olsa bile evienrne, Lex loci nazarında sahihtir. Dinî nikâhı kabul etmiş bazı devletler; vatandaşlarının Lex loci'ye uygun olarak akdettikleri evlenmeleri bu evlenme kendi topraklarinda hükümlerini meydana getirmiyecekse; sahih olarak tanurlar Arjantin Avusturya devletleri bu meyandadır (105). Yunanistan Srrbistan ve Bulgaristan gibi bazı devletler ise medenî nikâhtan sonra dinî merasimi yapılmamış olan bir evlenmeyi muteber saymazlar (106).

Dinî evlenmeyi kabul eden devletlerin medenî nikâha karşı almış oldukları bu vaziyet, insanın en tabî̂ bir hakkı olan evlenmeden tebaların mahrum etmek gibi bir netice doğurması itibariyle şayanı tenkittir.

EVLENME AKDININ TESCILI: Bazı kanunlar vatandaşlarının hariçteki evlenmelerini; kendi memleketlerinde tescil ettirmelerini öngörür. Fransa, İtalya ve Belçika kanunları böyledir. Bu tescilin yapilmamış olmasının akit mahalli ile diğer memleketlerde evlenmenin sthhati üzerine bir tesiri yoktur; eşlerin kendi memleketlerindeki müeyyidesini ise Millî kanunları tâyin eder. İsviçrede bu mecburiyeti vatandaşlarına tahmil eder; ve bu formalitenin yerine getirilmemesi halinde evlenmeyi yok (inexistant) addeder (107).

Türkiyede; hariçte yapılan evlenmelerin tescili hakkında "evlenme kayıtları ve bunları nüfus kütüğüne tescilleri hakkındaki 3686 sayılı ve 939 tarihli" kanunun üçüncü maddesinin ikinci fıkrasinda sarahat vardır. Bu fikra şöyledir "Türkiye haricinde yapılan evlenme akitleri konsolos tarafindan hariciye vekâleti vasitasiyle bildirilir. Ancak Türkiye haricinde konsoloshanelerden başka makamlarca yapilan evlenme akitlerinin bildirilmesi mecburiyeti kocaya aittir". 330 tarihli nüfus kanununun $28 / 2$ inci maddesinde "hariçte vâki evlenmelerin koca tarafından getirilecek vesika üzerine şehbender tarafindan usulen deftere kaydile hariciye nezaretine ve oradan da dahiliye vekâletine gönderileceği» yazılıdır (108). Fakat her

(104) ck. 237.

(105) Audinet: Sa: 195.

(106) Audinet: Sa: 195.

(107) Audinet: Sa: 195.

(108) Sicilli kavanin cilt: 20; Sa: 780; Sicilli kavanin cilt 16, Sa: 608 . 
iki kanununda da kocanın bu mükellefiyetini yerine getirmemesi halinde müeyyidenin ne olacağ meselesi, böyle bir mecburiyet tahmil eden Fransada da pek çok münakaşayı mucip olmuş, fakat neticede bunun evlenmenin butlanunı intaç etmişeyeceğine karar verilmişti (119). Evlenmenin butlanı bizim hukukumuzda da evlenmenin butlanın mucip sebepler tahdidî olarak tasrih edilmiş olduğundan herhalde böyle bir mükellefiyeti yerine getirmemenin müeyyidesi ancak cezâ̂ mahiyette olabilir.

KANUNA KARŞI HİYLE: (Fraude à la loi: Evleneceklerin; kendi Millî kanunlarmm bazı hükümlerinden kurtulmak maksadiyle hariçte evlenmelerine sık sık tesadüf edilir. Bazı kanunlar bu gaye ile aktedilmiş evlenmelerin; muteber sayılmıacağını tasrih ederler. İsviçre meriyet kanununun M. $59 / 7 \mathrm{f}$ fikrasinda böyle bir hüküm vardır. Kanuna karşı hiyle bazı memleketlerde hariçte aktedilmiş evlenmeleri iptal etmek için müracaat edilen bir çaredir. Meselâ bir vakitler Fransada 170 inci maddenin aradığı ilân şartının yerine getirilmeden yapılmı̧ evlenmeleri iptal için mahkemeler tarafından kullanılmakta idi (110).

Audinet; kanunun sarih olarak kanuna karşı hile gayesiyle aktedilen evlenmelerin, batıl addedileceğini tasrih etmediği yerlerde buna baş vurmamanın daha doğru olacağına işaret eder (111). Tarafların tâbi oldukları kanunun hükmünden kurtulmak maksadiyle böyle bir evlenme aktedip etmediklerinin tesbiti çok defa müşkül ve hattâ bazen imkânsızdır; bu esebeplerledir ki kurulmuş ve içtimaî ve ailevî bir çok neticeler meydana getirmiş bir müesseseyi; belki de bir faraziye üzerine yıkmak herhalde pek de yerinde olmasa gerektir. Zaten bir evlenmenin iptali için buna başvurmaya pek lüzum da yoktur; eşlerin, Millî kanunlarmm butlan sebeplerinden birine rağmen hariçte aktetmiş olduklar evlenme zaten sırf bu sebep dolayısiyle batıldır; alelâde mâni sebeplere rağmen yapılmış bir evlenmeyi sırf kanuna karşı hileye müsteniden iptal ise eşleri ve bu evlenmeden doğan çocukları çok ağır bir cezay̧a çarptırmak olur.

LA HEYE ANLASMASINDA EVLENMENIN SURÎ SARTLARININ TÂBt OLACAĞ ANUN HAKKINDA HƯKƯMLER:

Anlaşma prensip olarak L. R. A. kaidesini kabul eder Beşinci

(109) Pillet: Sa: 551 vd; Weiss: Sa: 494; Niboiyet: Sa: 725 vd.

(110) Niboyet: Sa: 273

(111) Audinet: Sa: 192. 
madresinin ilk fikrası bunu gösterir: «L. R. A. prensibine uygun olarak aktedilmiş bir evlenme her yerde muteberdirm. Lâkin dinî nikâhı evlenmenin aslî şartlarından olarak kabul etmiş devletlerin ve bilhassa Rusyanin (112) şiddetli itirazları üzerine maddenin bu fıkrasına "dinî nikâhı kabul etmiş devletlerin; vatandaşlarının hariçte buna riayet etmeden yapmıs oldukları evlenmeleri; sahih olarak tanıyı tanımamakta muhtar oldukları" hakkında bir kaydı ihtirazi konmustu.

Anlaşmanın yedinei maddesiyle de «akit mahallî kanunlarına göre şekil bakımindan batıl bir evlenmenin Millî kanun hükümlerine uygun olduğu takdirde diğer devletler tarafından muteber olarak kabul edilebileceği» hakkında bir hüküm konarak üicüncü şahıs vaziyetindeki devletler bu hususta muhtar birakmıştı.

Mukavele beşinci maddesinin üçüncü frkrasiyle de evlenme ilânlarına temas eder; maddeye göre aMillî kanunun ilân hakkkundaki hükümlerine riayet edilecektir, fakat bu ilânların yapılmamıs olması evlenmenin, ancak kanunlarma muhalefet edilmiş clan memlekette, butlanm icabettirir».

\section{DİPLOMATIK VE KONSÜLER EVLENMELER:}

Konsolos ve siyasî memurların haiz olduğu bu evlendirme memurluğu salâhiyeti; devletler arasında taammülen teessüs etmiş ve sonraları konsolosluk mukaveleleriyle de teyit ediimekte bulunulmuştur (113). Konsolosların böyle bir salâhiyeti haiz olabilmeleri bu salâhiyetin kendilerine; hem kendi devletleri tarafindan verilmiş ve hem de yabancl devletlerin bu yetkiyi tanmıs olmasma bağlıdtr; aksi takdirde konsolos bulunduğu memleketin iđarî salikhiyetine tecavüz etmiș olur.

La Heye anlaşmasından. sonra Holanda, İsveç gibi bazı devletler konsoloslarma ve siyasî memurlarına bu yetgiyi veren kanunlar yaptılar.

İspanya konsolosları bu salâhiyeti ancak evlındirme memuru bulunmiyan yerlerde haizdirler (114). Brezilya kanunu evlendirme memurluğu yetgisini yalnız konsoloslarma tanır (115). Yunanistan, Bulgaristan, Yogoslaşya kendi temsilcilerine bövle bir salâhiyet tanmazlar. İsviçre federal meclisi lüzum gördüşü memle-

(112) O zamanki Rusya Çarlık Rusyasıydi ve teokratik esaslara stkı surette bağlıydi.

(113) Türkiye ile Ermenistan, Azerbaycan, Polonya arasında böyle anlaşmalas varđur: Répertoire cilt 7; Sa: 268. 
ketler için konsoloslarma bu yetkiyi verebilir; fakat şimdiye kadar ancak Japonyadaki konsoloslarına böyle bir salâhiyet vermiştir (116).

Umumiyetle konsoloslar yalnız kendi tabaları arasında evlendirme yetgisini haizdirler. Fakat Almanya, İsvec ve Ingiltere bu hususta daha liberal davranarak taraflardan yalnız birinin konsolosun vatandaşı olmasını kâfi görür (117). Fransa, Belçika, İtalya ve İsveç te bunun koca olması lâzumdır. Bununla beraber Fransız konsoloslarmın böyle mikst bir evlenme yapabilmeleri; Fr. M. K. 170/1 mucibince bir kararname ile; bu yetkinin kendilerine verilmiş olmasına bağlıdır (118).

Weiss; Fransadaki ecnebi konsoloslarının evlendirme memurluğu salâhiyetlerinin yalnız kendi memleket vatandaşiarı arasında cari olacağmı söyler (119). İngiliz, Alman ve Belçika konsolosları böyle mikst bir evlendirme için kendi devletlerinden hususî bir müsaade almak zorundadırlar; ayni zamanda böyle bir evlendirmeye bulundukları memleketin müsaade etmiş olması da şarttır.

Türk konsoloslarına evlendirme memurluğu sıfatı 926 tarihli ve 505 sayılı kararname ile verilmiştir (120). Türkiye; Lozan muahedesinin 16 inci maddesiyle konsoloslarm; șahsî ahval işlerinde devletleri tarafınđan verilmiş olan salâhiyetlerine halel g̣elmiyeceğini kabul etmişti (21).

Kanunlarında konsolos ve diplomatlara bu yetginin tanın̈̈ı̆̆ hakkında bir hüküm bulunmıan devletlerin; memurlarına böyle bir salâhiyet verip vermediklerinin anlaşılması için; bu devletler tarafından takip edilegelmekte olan taamüle bakılması lâzımgeldiğine Pillet ișaret eder (122).

(114) Weiss: Sa: 497.

(115) Audinet: Sa: 205.

(116) Audinet: Sa: 205.

(117) Répertoire cilt 6 . Sa: 40 İngiliz siyasî temsilcilerine bu salâhiyet 1892 tarihli (Foreign marriage act) ile verilmiştir

(118) Fransız konsoloslarına bu salâhiyeet Habeşistan, İran; Siam, Çin, Surbistan ve Türkiye için tanınmıștır: «1901 tarihli kararname», Weiss: Sa: 495. Fakat bu kararnamedeki ,mucip sebeplerden anlaşlacağı üzere Türkiyedeki fransız konsoloslartnın bu yetkisinin artık sebebi hikmeti kalmamıştır: Répertoire: cilt 7: Sa: 267.

(119) Weiss: Sa: 497

(120) Sicilli kavanin: cilt 12 Sa: 656.

(121) Répertoire: Cilt 7; Sa: 268.

(122) Pillet: Sa: 580. 
$\mathrm{La}$ Heye anlaşması altıncı maddesiyle diplonatik evlenmelere temas eder; bu madde şöyledir:

(Diplomatik veya konsüler bir memur tarafından; şekil baklmından kendi kanunlarına uygun olarak aktedilmiş bir evlenme; taraflardan hiç bir evlenmenin icra edildiği devlet tebeasından olmadığı ve bu devlet tarafindan evlenmenin icrasına mümanaat edilmediği takdirde her yerde muteberdir.

Evlenmenin icra edildiği devlet; bu evlenmeye evvelden mevcut bir evlilik veya dinî bir moni dolayısiyle; kanunlarına muhalif olduğlindan bahisle mümanaat edemez".

Umumiyetle konsolosun; bulunduğu memleket vatandaşlarmdan biriyle kendi tâbi bulunduğu devlet tebaası arasında konsoloslukta aktettiği bir evlenmeye hiçbir yerde muteber nazariyle bakılamaz. Bir Fransiz mahkemesi (cour d'Anger) Fransada, bir Fransız ile bir İngiliz arasında İngiliz konsoloshanesinde aktedilmiş bir evlenmenin gayri mevcut olduğuna (inexistant) karar vermişti (123). İstanbulun işgali sirasında Rum ve Ermeni kuzlarının ecnebi sefarethanelerindeki evlenmelerini Türkiye sahih olarak kabul etmemişti. Ayni suretle Fransız temyiz mahkemesi de 1840 da Fransiz sefarethanesinde evlenmiş bir Türk kızının evlenmesinin batıI olduğuna karar vermişti (124).

Şekil bakımından konsolosun tatbik edeceği kanun kendi Millî kanunudur (125). Zaten koncüler evlenme, evlenmenin surî şartlarının Lex loci'ye tâbi olacağı kaidesine bir istisna teşkil eder. Bunu La Haye anlaşmasının altıncı maddesinden açık olarak anlamak mümkündür. N. Metya, «şekil bakımından Millî kanunun tatbikı için onun wevlenme kaidelerimize muhalif olmaması lâzımgeldiğini söyler ve bir konsoloshanede iptidaen yaplan bir dinî evlenmenin batıl olduğunu da ilâve eder (126)». A. Kemal bu hususta fikrini açık olarak söylememekle beraber "Millî kanuna göre dinî merasim icrası suretiyle evlenme mümkün olduğu takdirde, konsolosların nikâh akdi salâhiyeti devlete karş̧ bir sui istimal vesilesi olmamalıdır, medenî merasim icrası suretiyle evlenmeyi kabul etmiş bir devlet ülkesindeki konsoloshanedeki, dinî merasim icrası o memleketin umumâ intizamını ihlâl eder» demek suretiyle Metya'nın görüşünü

(123) Pillet: Sa: 545.

(124) N. Metya S: 127.

(125) M. R. Sevig: Sa: 365; Weiss: Sa: 497; Audinet: Sa: 208. Niboiyet: Sa: 729 . 
çevirtmekte olduğu hissini vermektedir (127). Halbuki Audinet ve Pillet; medenî evlenmenin cari olduğu bir memlekette bile konsoloshanelerinde dinî nikâhı kabul etmiş olan iki Devlet tebaasının kendi. Millì kanunlarma göre evlenebileceklerini kabul ederler (128). Konsüler evlenmelerin menşeiinin; siyasî temsilcilerin eksteritorial (exterritorial) imtiyazdan istifadelerinin bir devamı gibi gören Pillet; böyle bir evlenmenin mümkün olmasinin da ancak bu prensiple izah edilebileceğini de ilâve eder (129).

Fakat bu şekildeki dinî evlenmeler; ancak evlendirme memuru sifatmı haiz biri tarafindan aktedilmeleri halinde muteberdir, meselâ bu sıfatı haiz bir konsoloshane papazı tarafından icra edilmesi halinde. Böyle resmî bir sıfatı olmıyan bir din adamı tarafından konsoloshanede icra edilen evlenme muteber addedilemez. Paris mahkemesi bu şekilde Yunan sefaretinin kilisasında aktedilmiş olan bir evlenmeyi muteber saymamıştı. Konsoloshane dinî memurları evlendirme memuru yetgisine haiz olmadikları takdirde, konsolos makamina geçmeleri de kabul olunamaz (130).

Konsüler evlenmelerde surî şartların; La Heye anlaşmasiyle de, Millî kanuna tâbi olacağını görmüştük. Bu anlaşma altıncı maddesiyle; ilânlar hakkındaki M: $5 / 3$ deki ihtirazî kaydın konsüler ve diplomatik evlenmelerde de tatbik edileceğini kabul eder.

oKsnüler evlenmenin aslî şartlar bakımmian tâbi olacağı kanunda yine millî kanundur.

Konsolos kendi Millî kanununu tatbik edecektir. O; bu kanunu tatbik ederken tabiidir ki kendi devletinin kamu intizamı kaidelerini göz önünde tutacaktır. Lâkin acaba mahallî kamu intizamını da dikkat nazarına almak zorunda mıdrr? Burada şöyle bir ayırma yapmak mümkündür:

a) Konsolos; Millî kanunu tarafından menedilmiş olmasına rağmen; mahallî kanunca kamu intizamı kaygusiỳle möisaade edilmiş bir evlenmeyi aktedemez. Bu hususta münhasiran kendi kanununu nazarı itibare alacaktır. Bir Sirp konsolosu dinî bir memnuiyet bulunmiyan Türkiyede veya Belçikada kendi tebaasından olan bir yahudi ile bir hiristiyanı evlendirememelidir.

(126) N. Metya: Sa: 127.

(127 A. Kemal: Sa: 4537 vd.

(128) Audinet: Sa: 208; Pillet: Sa: 546.

(129) Pillet: Sa: 545.

(130) A. Kemal: Sa: 4536; Audinet: Sa: 208. 
kanunun bu mânilerini göz önünde tutmak zorundadır. Çünkü böyle bir evlenme en evvel tesirlerini konsolosun bulundugu memlekette gösterecektir (131). Fakat La Heye anlaşmasının altmo maddesi bundan ikinci bir evliliği ve dinî mânileri istisna etmektedir.

Konsoloslar akdettikleri evlenmeleri re'sen tescil ederler (132).

(131) Pillet: Sa: 446; Audinet: Sa: 409; ayni fikirdedirler.

(132) Niboyet: Sa: 729. 